\title{
Alkalmas-e a vizelet neutrofil gelatináz asszociálta lipokalin meghatározása a rejekció előrejelzésére veseátültetés után?
}

\author{
Telkes Gábor dr. - Dallos Gábor dr. - Varga Marina dr. \\ Semmelweis Egyetem, Általános Orvostudományi Kar, Transzplantációs és Sebészeti Klinika, Budapest
}

\begin{abstract}
Bevezetés: Veseátültetés után mind a graft késleltetett múködése, mind az akut rejekció negatívan befolyásolja a túlélést. Célkitüzés: A neutrofil gelatináz asszociálta lipokalin ígéretes biomarkernek tủnik az akut károsodások diagnózisában. Módszer: Prospektív vizsgálatban 27 felnőtt veserecipiens vizelet neutrofil gelatináz asszociálta lipokalin értékét mérték és megvizsgálták prediktív értékét. Eredmények: A betegeket 4 csoportba osztották (nincs komplikáció, rejekció, késői indulás dialízisigénnyel, rejekció + késői indulás). Nem találtak szignifikáns különbséget a nincs komplikáció és rejekció, valamint a késői indulás dialízisigénnyel és rejekció + késői indulás csoportok között. A késői indulás dialízisigénnyel és rejekció + késői indulás csoportok neutrofil gelatináz asszociálta lipokalin szintje lényegesen magasabb volt, mint a nincs komplikáció és rejekció csoportoké. A nincs komplikáció és rejekció csoportokban a kreatinin és neutrofil gelatináz asszociálta lipokalin szintjei párhuzamosan változtak. Következtetések: A vizsgált betegekben a neutrofil gelatináz asszociálta lipokalin nem adott hasznos információt sem jó, sem gyengén induló graftmúködés esetén. Orv. Hetil., 2015, 156(48), 1956-1959.
\end{abstract}

Kulcsszavak: akut vesekárosodás, graftrejekció, vesetranszplantáció, neutrofil gelatináz asszociálta lipokalin

\section{Can urinary neutrophil gelatinase-associated lipocalin predict acute rejection following deceased donor kidney transplantation?}

\begin{abstract}
Introduction: Delayed graft function and acute rejection have negative impact on graft survival. Aim: To asses the predictive value of urinary neutrophil gelatinase-associated lipocalin, which has been found to be a promising biomarker for the diagnosis of acute kidney injury. Method: In this prospective study urinary neutrophil gelatinase-associated lipocalin levels of 27 kidney recipients were measured. Results: Patients were grouped as follows: group 1, no complication; group 2, rejection; group 3, delayed graft function requiring dialysis; group 4, rejection plus delayed graft function. There were no significant differences between groups 1 and 2 , and between groups 3 and 4 . Patients in groups 3 and 4 had significantly higher urinary neutrophil gelatinase-associated lipocalin levels as compared to those in groups 3 and 4 . There was a paralIel change in urinary neutrophil gelatinase-associated lipocalin levels in groups 1 and 2. Conclusions: In these patients urinary neutrophil gelatinase-associated lipocalin levels failed to provide useful information in both cases of normal and impaired function.
\end{abstract}

Keywords: acute kidney injury, graft rejection, kidney transplantation, neutrophil gelatinase-associated lipocalin

Telkes, G., Dallos, G., Varga, M. [Can urinary neutrophil gelatinase-associated lipocalin predict acute rejection following deceased donor kidney transplantation?]. Orv. Hetil., 2015, 156(48), 1956-1959.

(Beérkezett: 2015. szeptember 22.; elfogadva: 2015. október 15.)

\section{Rövidítések}

$\mathrm{AKI}=$ (acute kidney injury) akut vesekárosodás; $\mathrm{AR}=$ akut rejekció; CIT $=($ cold ischaemic time $)$ hideg ischaemiás idő;
DGF = (delayed graft function) késleltetett graftfunkció; $\mathrm{GFR}=$ glomerularis filtrációs ráta; $\mathrm{NGAL}=$ neutrofil gelatináz asszociálta lipokalin 
Vesetranszplantáció után a graft funkciója széles skálán változik. Az azonnali, kiváló funkciót a gyors kreatinincsökkenés, GFR növekedése jellemzi bőséges diuresis mellett. A másik véglet, amikor a beültetett vese nem kezd azonnal vizeletet elválasztani. Amennyiben a transzplantációt követő egy héten belül dialízisre (HD) van szükség, késleltetett graftindulásról, elterjedt angol elnevezéssel „delayed graft function”-ról (DGF) beszélünk. Ez az esetek 20-33\%-ban fordul elő [1]. A DGF oka akut vesekárosodás (AKI), elsősorban a szervdonáció során fellépő ischaemia-reperfúzió hatására. A szervkivételtől az ismételt keringésbe kötésig tartó hideg ischaemiás idő (CIT) a DGF legfontosabb bizonyított prediktora.

A transzplantáció utáni időszakban az akut rejekció (AR) az egyik legfontosabb, szintén akut károsodást okozó tényező. Ezeken felül fertőzések, gyógyszertoxicitás is okozhat AKI-t.

Mind a rejekciós epizódok, mind a DGF negatívan befolyásolják a vesegraft hosszú távú múködését és élettartamát $[2,3]$. Korántsem mellesleg párhuzamosan is felléphetnek a korai posztoperatív fázisban, ráadásul a hosszabb CIT növeli a rejekciók gyakoriságát $[4,5]$. DGF esetén a vesefunkciós paraméterek nem használhatók a háttérben zajló rejekció gyanújának felvetésére, amelyet így csak invazív vesebiopszia végzésével lehet igazolni/kizárni.

Nagy előrelépést jelentene, ha noninvazív módszerekkel a biopsziavétel elkerülhetővé válna. Ehhez megfelelő biomarkerekre van szükség, amelyek kellő biztonsággal jelzik a vesekárosodás mértékét, lehetőleg okát is [1]. Számos vizsgálatban több különböző lehetséges biomarker vizsgálatára került sor. Ezek közül potenciális használhatóságával kiemelkedni látszik a neutrofil gelatináz asszociálta lipokalin (NGAL), mint az akut vesekárosodás új markere $[6,7,8]$.

Az NGAL a lipokalincsaládba tartozó, 25 kDa súlyú fehérje. Külső károsító hatásokra számtalan sejtféleség, köztük kiemelten a vesetubulusok sejtjei NGAL-t termelnek. A vizeletben NGAL megjelenése akkor valószínú, ha a károsodásban a proximális tubulussejtek érintettek, fokozva ott a de novo NGAL-szintézist, illetve gátolva annak reabszorbcióját [9]. Egyes vizsgálatokban az NGAL klinikai körülmények között is az AKI ígéretes prediktorának bizonyult. Egy száz transzplantált betegre kiterjedő keresztmetszeti vizsgálat során a szérumban mért NGAL-szint korrelált a vesefunkcióval [10]. Ezeket az adatokat azonban kutatási céllal fejlesztett és használt mérési módszerekkel gyưjtötték, amelyek így napi klinikai körülmények között csak kevéssé használhatók.

Vizsgálatunkban egyrészt arra kerestük a választ, hogy vizelettel kiválasztott NGAL alkalmas-e a rejekció előrejelzésére. Vizsgáltuk, hogy ez a biomarker meg tudja-e különböztetni transzplantáció után azt az állapotot, amikor „csak” később kezd dolgozni a vesegraft (DGF), attól, amikor erre kilökődés is rakódik. A vizsgálat nullhi- potézise szerint a rejekció nem okoz különbséget az NGAL mértékében.

\section{Módszer}

Prospektív, megfigyeléses vizsgálatot végeztünk. Klinikánk évi 180-230 közötti veseátültetést végez. A méréseket 27, egymást követő, első cadavervese-átültetésben részesült felnőtt betegen végeztük. A betegek közül 15 (56\%) volt férfi, átlagéletkor 47,3 év ( \pm SD: 11,8; 29$73)$. A hideg ischaemiás idő 13,5 h $( \pm S D: 3,3 ; 6,7-22,4)$. Protokoll szerinti immunszuppressziót alkalmaztunk: tacrolimus, amelynek kezdő adagja $0,1 \mathrm{mg} / \mathrm{kg}$ naponta kétszer, a célszint 10-12 ng/ml. Mycophenolat-mofetil naponta kétszer $1000 \mathrm{mg}$, valamint kortikoszteroid: a mútétkor $500 \mathrm{mg}$ metilprednisolon iv., az első napon $125 \mathrm{mg}$ iv., majd napi $20 \mathrm{mg}$ szájon át, a második héttől fokozatosan csökkentve. A beültetett vese keringését ultrahanggal ellenőriztük, a vizsgálatból minden vascularis és ureterkomplikációt kizártunk. A rejekciót szövettani vizsgálattal igazoltuk. Biopsziát az alábbi esetekben vettünk:

a) a kezdeti jó graftfunkció romlása, vagy

b) 7 napnál hosszabb DGF; ez esetben a 7-10. nap között került sor a mintavételre.

Egy héten belül javuló DGF esetén nem történt biopsziavétel. A vesefunkciót a napi diuresis mérésével és a szérumkreatinin meghatározásával mértük, a GFR becsléséhez a Cockcroft-Gault-formulát használtuk. DGF-nek tekintettük, ha az első posztoperatív héten dialíziskezelésre volt szükség. A vizeletmintákat a katéterzsákból vagy a reggeli vizeletből vettük a posztoperatív első, harmadik, ötödik, hetedik és tizedik napon. A mérés a vizelet-NGAL kvantitatív mérésére kifejlesztett és validált „chemiluminescent microparticle immunoassay (CMIA)" módszerrel történt (Architect, Abbott).

Normáleloszlású folytonos változókat az átlag és a standard deviáció (SD) megadásával, nem normáleloszlásúakat a medián megadásával jellemeztük. Nemparametrikus összehasonlításra Mann-Whitney-féle U- vagy több csoport esetén Kruskal-Wallis-tesztet használtuk. A binomiális változókat Fisher egzakt, vagy $\chi^{2}$-teszttel elemeztük, kétoldalas valószínúségi értéket adtunk meg. A p értékét minden esetben 0,05 alatt tekintettük szignifikánsnak. A statisztikai számításokhoz a StatSoft, Inc. (2014). Statistica (data analysis software system), version 12. (www.statsoft.com) szoftvert használtuk.

\section{Eredmények}

A klinikum alapján nyolc esetben vettünk biopsziát. Ebből öt $(18,5 \%)$ esetben igazolódott akut rejekció. Összesen nyolc $(29,3 \%)$ betegnek volt DGF-je, ők igényeltek dialíziskezelést. Közülük 3 betegben még rejekció is fellépett. 
1. táblázat | Posztoperatív NGAL-értékek (ng/ml) az egyes csoportokban

\begin{tabular}{|c|c|c|c|c|}
\hline Napok & $\begin{array}{l}\text { „S” csoport } \\
\text { (17 fó) }\end{array}$ & $\begin{array}{l}\text { "R" csoport } \\
(2 \text { fo) }\end{array}$ & $\begin{array}{l}\text { „HD” csoport } \\
(5 \text { fö) }\end{array}$ & $\begin{array}{l}\text { "HDR" csoport } \\
\text { (3 fo })\end{array}$ \\
\hline 1. & $\begin{array}{l}632 \\
(58-2750, \\
\text { std: } 742)\end{array}$ & $\begin{array}{l}251 \\
(166-335, \\
\text { std: 119) }\end{array}$ & $\begin{array}{l}370 \\
(181-1802, \\
\text { std: } 847)\end{array}$ & $\begin{array}{l}1168 \\
(708-1804, \\
\text { std: } 568)\end{array}$ \\
\hline 3. & $\begin{array}{l}202 \\
(16-1158, \\
\text { std: } 270)\end{array}$ & $\begin{array}{l}99 \\
(42-156, \\
\text { std: } 80)\end{array}$ & $\begin{array}{l}2901 \\
(722-5079, \\
\text { std: } 2405)\end{array}$ & $\begin{array}{l}2566 \\
(1655-3478, \\
\text { std: } 1289)\end{array}$ \\
\hline 5. & $\begin{array}{l}128 \\
(22-660, \\
\text { std:156) }\end{array}$ & $\begin{array}{l}87 \\
(57-118 \\
\text { std: } 43)\end{array}$ & $\begin{array}{l}1212 \\
(218-3122, \\
\text { std: } 1425)\end{array}$ & $\begin{array}{l}3376 \\
(569-6429, \\
\text { std: } 2937)\end{array}$ \\
\hline 7. & $\begin{array}{l}141 \\
(17-912, \\
\text { std: } 221)\end{array}$ & $\begin{array}{l}71 \\
(52-91, \\
\text { std: } 28)\end{array}$ & $\begin{array}{l}152 \\
(86-176, \\
\text { std: } 39)\end{array}$ & $\begin{array}{l}2764 \\
(112-6239 \\
\text { std: } 3144)\end{array}$ \\
\hline 10. & $\begin{array}{l}94 \\
(12-403, \\
\text { std: } 105)\end{array}$ & $\begin{array}{l}43 \\
(37-50, \\
\text { std: } 9,9)\end{array}$ & $\begin{array}{l}77 \\
(48-85, \\
\text { std: } 18)\end{array}$ & $\begin{array}{l}1168 \\
(48-2300, \\
\text { std: } 1125)\end{array}$ \\
\hline & \multicolumn{2}{|c|}{ n. $s$} & \multicolumn{2}{|c|}{ n. s. } \\
\hline
\end{tabular}

std = standard deviáció; $n$. s. = nem szignifikáns.

2. táblázat | A p értékei az egyes csoportok NGAL-szintjei között

\begin{tabular}{lll}
\hline Napok & „S” vs. „HD” & „S” vs. „HDR” \\
\hline 1. & n. s. $(0,55)$ & n. s. $(0,12)$ \\
3. & 0,007 & 0,012 \\
5. & 0,009 & 0,004 \\
7. & n. s. $(0,14)$ & 0,040 \\
10. & n. s. $(1,0)$ & n. s. $(0,11)$ \\
\hline
\end{tabular}

n. s. = nem szignifikáns.

A nem, a DGF és a rejekciók között nem tudtunk kapcsolatot kimutatni. A betegeket a kórlefolyás alapján az alábbi 4 csoportba osztottuk.

- „ऽ” csoport: zavartalan posztoperatív fázis, sem $\mathrm{AR}$, sem DGF, 17 (63\%) beteg;

- „R” csoport: jól induló graft és AR lép fel, 2 (7,4\%) beteg;

- „HD” csoport: DGF észlelhető, de nincs AR, 5 $(18,5 \%)$ beteg;

- „HDR” csoport: DGF mellé AR is társul, $3(11,1 \%)$ beteg.

E csoportok átlagos NGAL-értékeit az 1. táblázatban, részletesebb p-értékeit a 2. táblázatban mutatjuk be.

Összehasonlítottuk a jó graftfunkcióval induló, tehát az „S” és az „R” csoportok betegeinek kreatinin- és NGAL-szintjeit. Mindkét csoporton belül a kreatinin és az NGAL értékei párhuzamosan alakultak, jó korrelációval: az „S” csoportban $\mathrm{r}=0,73, \mathrm{p}=0,042, \mathrm{az}, \mathrm{R}$ ” csoportban $\mathrm{r}=0,98, \mathrm{p}=0,0006$. A két csoport NGAL-értékeit egymással összehasonlítva azt tapasztaltuk, hogy azok között egyetlen posztoperatív napon sem volt szignifikáns különbség. Ezt demonstrálja az 1. ábra.

Vizsgáltuk, hogy bármely vizsgált tényezőnek (nem, kor, CIT, DGF, tacrolimusszint, kreatinin, NGAL) van-e

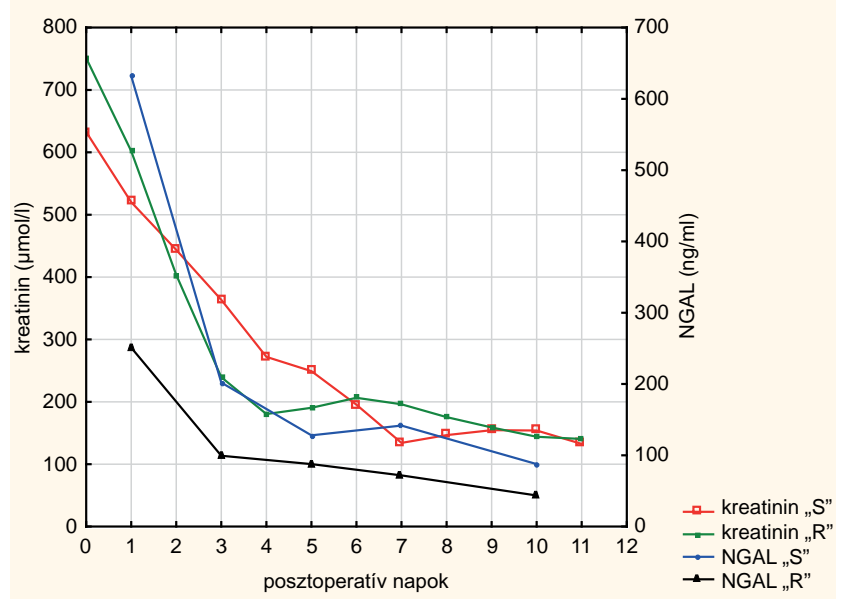

1. ábra |Az „S” és „R” csoportok kreatinin- és NGAL-értékei

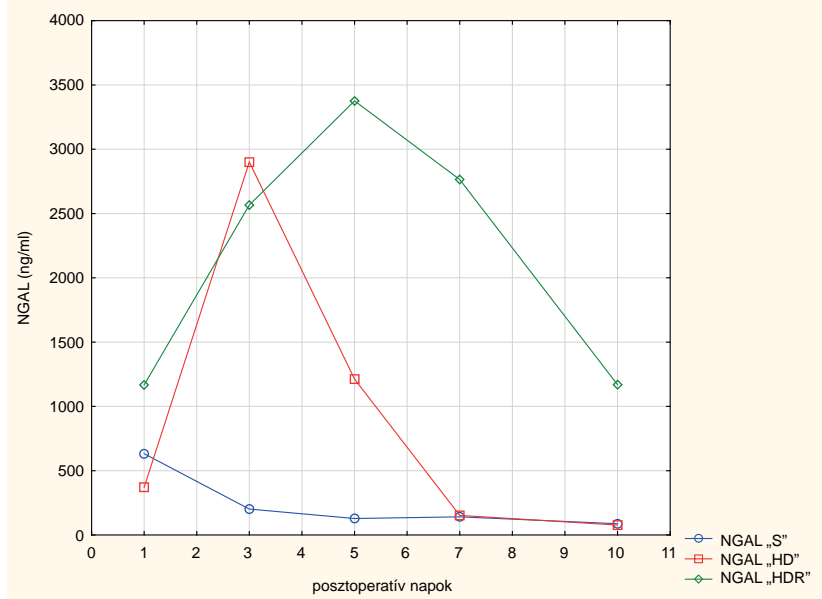

2. ábra | Az „S”, „HD” és „HDR” csoportok NGAL-értékei

prediktív jelentősége a rejekciót illetően. Fentiek közül a 7. napon mért kreatinin és NGAL is a rejekció prediktív faktorának bizonyult, a p értékei 0,006 , illetve 0,048 . A többi tényező hatása, illetve a többi napon mért értékek nem bizonyultak szignifikánsnak.

DGF esetén sokkal magasabb NGAL-értékeket mértünk, ami gyorsan csökkent a vesefunkció visszatérésével. DGF mellé, „rárakódó” rejekció esetében ezek az értékek még magasabbra szöktek, és csak 3-4 nappal később kezdtek csökkenni, ahogy a 2. ábra mutatja. Az „S” csoporthoz képest a különbség markánsan szignifikáns, de a "HD” és a „HDR” csoportok között nem (1. és 2. táblázat, 2. ábra).

\section{Megbeszélés}

$\mathrm{Az}$ „S” és „R” csoportokban mind a kreatinin, mind a vizelet NGAL-értékei párhuzamosan változtak, így az NGAL-mérések nem adtak további információt. A klinikai gyakorlatban a 4-7. nap körül a kreatininértékek csökkenés utáni ismételt emelkedése, „hintázása” na- 
gyon jellemző akut rejekció esetén, és a biopsziavétel indikációja. Az NGAL-értékek azonban nem mutatták ugyanezt a jelenséget (1. ábra). Csak a 7 . napi NGALérték bizonyult prediktívnek a rejekciót illetően.

Ellentmondásos kapcsolat van a DGF és az akut rejekció között. A DGF maga is a rejekció egyik rizikótényezóje, és vice versa, a DGF elhúzódása mögött gyakran tünetszegény rejekció lappang $[4,5]$. Ráadásul a DGF graftúlélésre gyakorolt negatív hatását is részben a gyakoribb rejekcióval magyarázzák. A hideg ischaemia a DGF egyik legfontosabb prediktora, ugyanakkor időtartama, a CIT, óránként 4\%-kal növeli a rejekció kockázatát is [11]. DGF esetén a klinikai jelek, tünetek - mint a vizelet mennyiségének csökkenése, a kreatinin ismételt emelkedése - nem használhatók a rárakódó rejekció felvetésére. Ilyen esetben ezért a rejekció kizárására egy hét után biopsziát kell venni a transzplantált veséból, ami invazív beavatkozás és bizonyos kockázatokkal jár. Ennek kiváltása egy megbízható, noninvazív vizsgálattal nagyon komoly előrelépést jelentene. Igazán komoly eredmény az lenne, ha a biopsziavételt teljesen el lehetne kerülni, de már az is segítséget nyújtana, ha jelezné a biopsziavétel szükségességét. Anyagunkban a DGF( „HD” és „HDR”) betegek NGAL-szintjei sokkal magasabbak voltak, mind az „S”, mind az „R” csoporthoz képest. Ez az eredmény természetesen alátámasztotta a DGF tényét, ez azonban nem egy komoly előny, hiszen ezt szofisztikált tesztek nélkül is észleltük. Ennél sokkal ígéretesebbnek látszik a „HD” és a „HDR” csoportok közötti különbség. Ez látványossága ellenére, sajnos, statisztikailag nem szignifikáns, valószínúleg az egyes csoportok csekély esetszáma miatt.

Az NGAL-mérések értékeit több zavaró tényező is befolyásolhatja, mint például hypertensio, infekció stb. Egy német vizsgálat során is azt tapasztalták, hogy transzplantált betegekben a vizelet-NGAL szenzitivitása túl alacsonynak bizonyult, és ez erősen limitálja a használhatóságát [12]. Ez megerősíti saját tapasztalatainkat is.

Klinikánk gyakorlata (sok más transzplantációs központhoz hasonlóan) az érvényes szakmai útmutatásoknak megfelelően az, hogy 7-10 nap között biopsziát veszünk, ha a vesegraft múködése ez alatt nem indul meg $[4,5,6,7,8,9,10,11,12,13]$.

Anyagunkban a vizelet-NGAL mérése sem jó, sem rossz kezdeti graftmúködés esetén biztosított további, a kezelésben is hasznosítható támpontot. Tapasztalataink alapján a nullhipotézist nem tudtuk elvetni. A bevont viszonylag kis esetszám miatt további vizsgálatok lehetnek szükségesek.

Anyagi támogatás: A munka a Magyar Nephrologiai Társaság kutatásfejlesztési pályázatán elnyert támogatásból valósult meg.

Szerzői munkamegosztás: T. G.: Tervezte a vizsgálat menetét, végezte az adatgyújtést, megírta a közleményt.
D. G.: Részt vett a pályázat elkészítésében, a betegek ellátásában, segített az adatgyújtésben. V. M.: Tervezte a laboratóriumi vizsgálatok menetét, megszervezte, kivitelezte és ellenőrizte azokat, részt vett a közlemény megfogalmazásában. A cikk végleges változatát valamennyi szerző elolvasta és elfogadta.

Érdekeltségek: A szerzőknek nincsenek érdekeltségeik.

\section{Köszönetnyilvánítás}

E helyen is köszönetet mondunk a Magyar Nephrologiai Társaság támogatásáért.

\section{Irodalom}

[1] Hall, I. E., Yarlagadda, S. G., Coca, S. G., et al.: IL-18 and urinary NGAL predict dialysis and graft recovery after kidney transplantation. J. Am. Soc. Nephrol., 2010, 21(1), 189-197.

[2] Yarlagadda, S. G., Coca, S. G., Formica, R. N., et al.: Association between delayed graft function and allograft and patient survival: a systematic review and meta-analysis. Nephrol. Dial. Transplant., 2009, 24(3), 1039-1047.

[3] Salahudeen, A. K., Haider, N., May, W.: Cold ischemia and the reduced long-term survival of cadaveric renal allografts. Kidney Internat., 2004, 65(2), 713-718.

[4] Kidney Disease: Improving Global Outcomes (KDIGO) Transplant Work Group: KDIGO clinical practice guideline for the care of kidney transplant recipients. Am. J. Transplant., 2009, 9(Suppl. 3), S1-S155.

[5] Qureshi, F., Rabb, H., Kasiske, B. L.: Silent acute rejection during prolonged delayed graft function reduces kidney allograft survival. Transplantation, 2002, 74(10), 1400-1404.

[6] Soni, S. S., Cruz, D., Bobek, I., et al.: NGAL: a biomarker of acute kidney injury and other systemic conditions. Int. Urol. Nephrol., 2010, 42(1), 141-150

[7] Clerico, A., Galli, C., Fortunato, A., et al.: Neutrophil gelatinaseassociated lipocalin (NGAL) as biomarker of acute kidney injury: a review of the laboratory characteristics and clinical evidences. Clin. Chem. Lab. Med., 2010, 50(9), 1505-1517.

[8] Coca, S. G., Yalavarthy, R., Concato, J., et al.: Biomarkers for the diagnosis and risk stratification of acute kidney injury: a systematic review. Kidney Int., 2008, 73(9), 1008-1016.

[9] Devarajan, P.: Neutrophil gelatinase-associated lipocalin - an emerging troponin for kidney injury. Nephrol. Dial. Transplant., 2008, 23(12), 3737-3743.

[10] Malyszko, J., Malyszko, J. S., Mysliwiec, M.: Serum neutrophil gelatinase-associated lipocalin correlates with kidney function in renal allograft recipients. Clin. Transplant., 2009, 23(5), 681686.

[11] Mikhalski, D., Wissing, K. M., Ghisdal, L., et al.: Cold ischemia is a major determinant of acute rejection and renal graft survival in the modern era of immunosuppression. Transplantation, 2008, 85(7 Suppl.), S3-S9.

[12] Kaufeld, J. K., Gwinner, W., Scheffner, I., et al.: Urinary NGAL ratio is not a sensitive biomarker for monitoring acute tubular injury in kidney transplant patients: NGAL and ATI in renal transplant patients. J. Transplant., 2012, 2012, 563404.

[13] European Renal Best Practice Transplantation Guideline Development Group: ERBP guideline on the management and evaluation of the kidney donor and recipient. Nephrol. Dial. Transplant., 2013, 28(Suppl. 2), iil-ii7l.

(Telkes Gábor dr.,

Budapest, Baross u. 23., 1082

e-mail: telkes.gabor@med.semmelweis-univ.hu) 